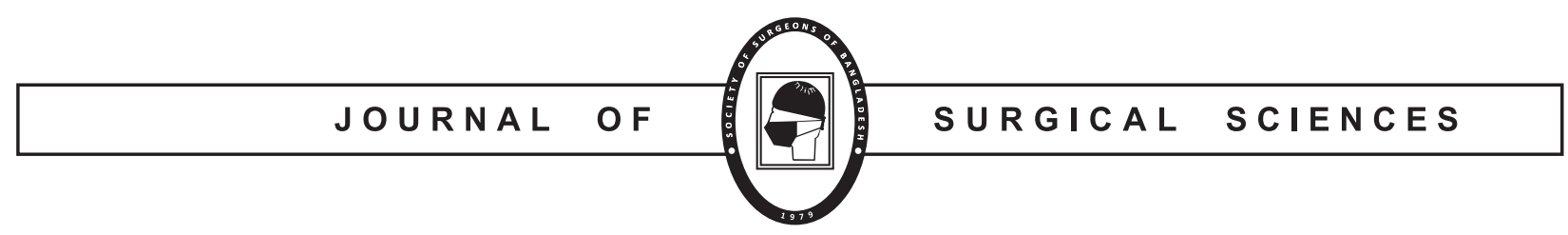

\title{
From the Desk of Editor in Chief
}

\section{Dear members,}

Greetings from the editorial board of journal surgical sciences (JSS), the official organ of the Society of Surgeons of Bangladesh. I am writing with utmost grief and with a saddened mind in this terrible pandemic due to SARS COV 2 infection. At the beginning of the year we were hopefully expecting brighter and more dynamic activities from the Society of Surgeons of Bangladesh. But unfortunately the whole world came to a standstill due to this deadly virus. The editorial board does understand the impact of this situation on the academic and professional activities of the members of the society. Despite different refrains, limitations and fear for getting infected by this notorious virus the members of the society are in progress using virtual platforms time to time. We do like to congratulate all the members of the society for accepting the overwhelming challenges to carry on the society activities with the same and even greater pace.

Stay safe and be blessed.

Professor Md. Ibrahim Siddique

Editor in Chief

Journal of Surgical Sciences

Society of Surgeons of Bangladesh 